\title{
TELAAH KETENTUAN PIDANA KEKARANTINAAN \\ KESEHATAN BERDASARKAN UNDANG-UNDANG NOMOR 6 \\ TAHUN 2018 BAGI KESEHATAN NOTARIS DAN MASYARAKAT \\ ERA PANDEMI COVID-19
}

\author{
M. Aris Munandar \\ Magister Ilmu Hukum Universitas Hasanuddin, Makassar, \\ m.arismunandar85@yahoo.co.id \\ Audyna Mayasari Muin \\ Fakultas Hukum Universitas Hasanuddin, Makassar, \\ audynamayasari@gmail.com \\ Hijrah Adhyanti Mirzana \\ Fakultas Hukum Universitas Hasanuddin, Makassar, \\ adhyantihijrah@gmail.com
}

\begin{abstract}
Abstrak
Penelitian ini bertujuan untuk mengetahui kebijakan hukum pidana yang menghambat penerapan status darurat kesehatan masyarakat pada saat diselenggarakan kekarantinaan kesehatan dan menganalisis sistem pemidanaan yang ideal untuk diterapkan bagi pelaku tindak pidana kekarantinaan kesehatan. Metode penelitian yang digunakan adalah penelitian hukum normatif melalui pendekatan perundang-undangan (statute approach). Hasil penelitian menunjukkan bahwa secara teoretis kebijakan hukum pidana dalam darurat kesehatan notaris dan masyarakat sulit untuk diterapkan. Substansi Pasal 93 UU Kekarantinaan Kesehatan memuat 2 (dua) jenis delik, yaitu delik formil dan delik materiel. Namun, terdapat penggunaan kata yang masih abstrak di antaranya: perbuatan "menghalanghalangi" serta menempatkan "kedaruratan kesehatan" sebagai "sebab" dalam peraturan tersebut merupakan sebuah kerancuan. Seharusnya rumusan kausalitas pidana dalam sebuah produk hukum pidana dirumuskan sesuai dengan konsepsi awalnya. Oleh karena itu, rumusan delik yang abstrak atau luas akan menghasilkan ketidakpastian hukum, berpotensi tidak dapat diterapkan, dan bertentangan dengan penafsiran yang menyatakan bahwa hukum pidana harus ditafsirkan secara sempit. Merujuk pada keadaan tersebut, maka sistem pemidanaan yang ideal diterapkan ketika terjadi pelanggaran penyelenggaraan kekarantinaan kesehatan, yaitu sistem pemidanaan yang bersifat restoratif dan integratif.
\end{abstract}

Kata kunci: Pandemi Covid-19, Kekarantinaan Kesehatan, Kebijakan Hukum Pidana 


\section{Abstract}

This study aims to determine the legal policy policies that apply Law Number 6 of 2018 concerning Health Quarantine and analyze the ideal punishment system to be applied to health quarantine crimes. The research method used, namely normative research through an invited approach (statute approach). The results show that legal policies in notarial and public health emergencies are difficult to implement. The substance of Article 93 of the Health Quarantine Law contains 2 types of offenses, namely formal offenses and material offenses. However, there is a use of the word which is still abstract beside: the act of "obstructing" and placing "health emergency" as "cause" in the regulation is a confusion. The formulation of criminal causality in a criminal law product should be formulated in accordance with its initial conception. Therefore, the abstract or broad formulation of offenses will provide legal uncertainty, which cannot be applied, and contradicts the interpretation which states that criminal law must be interpreted narrowly. Referring to this situation, the ideal punishment system is applied when implementing health quarantine, namely a restorative and integrative system of punishment.

Keywords: Covid-19 Pandemic, Health Quarantine Act, Penal Policy

\section{PENDAHULUAN}

Indonesia sebagai negara hukum (rechtsstaat) berupaya mencapai negara hukum yang komprehensif dalam penegakan hukum, khususnya ketika terjadi wabah atau pandemi virus tertentu. Oleh karena itu, Pemerintah bersama Dewan Perwakilan Rakyat Republik Indonesia (DPR RI) telah menerbitkan beberapa undang-undang, yaitu Undang-Undang Nomor 4 Tahun 1984 tentang Wabah Penyakit Menular, Undang-Undang Nomor 24 Tahun 2007 tentang Penanggulangan Bencana, dan UndangUndang Nomor 6 Tahun 2018 tentang Kekarantinaan Kesehatan (UU Kekarantinaan Kesehatan). Berlakunya UU Kekarantinaan Kesehatan diharapkan memberikan kepastian hukum terhadap pengendalian dan pencegahan penularan virus yang signifikan. UU tersebut tidak hanya mengatur terkait aspek teknis pencegahan serta pengendalian penyebaran virus, tetapi juga berkenaan dengan penerapan sanksi pidana ketika terjadi suatu kedaruratan kesehatan.

Coronavirus Disease 2019 merupakan salah satu peristiwa atau fenomena hukum dan kesehatan yang terjadi secara global. Chinese Center for Disease Control and Prevention merupakan lembaga yang pertama kali mengumumkan bahwa telah ditemukan virus jenis baru (SARS-CoV-2) yang selanjutnya disebut Covid-19 dan pertama kali ditemukan di Wuhan, 
TELAAH KETENTUAN PIDANA KEKARANTINAAN KESEHATAN BERDASARKAN UNDANGUNDANG NOMOR 6 TAHUN 2018 BAGI KESEHATAN NOTARIS DAN MASYARAKAT ERA PANDEMI COVID-19 (M. Aris Munandar, Audyna Mayasari Muin, Hijrah Adhyanti Mirzana) China. Setelah penyebaran Covid-19 mengalami peningkatan secara signifikan, maka World Health Organization (WHO) mengumumkan pada tanggal 11 Maret 2020 bahwa Covid-19 sebagai pandemi global. ${ }^{1}$ Peristiwa ini akhirnya menyebabkan beberapa melakukan segala cara untuk menekan penyebaran virus, salah satunya dengan membuat regulasi untuk penanganan Covid-19.

Keberadaan UU Kekarantinaan Kesehatan membawa hal yang baru bagi Indonesia dalam menyikapi setiap wabah penyakit. Data Pemerintah Republik Indonesia bahwa sampai 13 November 2020 jumlah kasus Covid19 terkonfirmasi sebanyak 457,735 orang (+5,444 kasus), kasus aktif sebanyak 57,604 orang (12,6\% dari terkonfirmasi), sembuh sebanyak 385,094 orang (84,1 \% dari terkonfirmasi), dan meninggal mencapai 15 . 037 orang $\left(3,3 \%\right.$ dari terkonfirmasi). ${ }^{2}$

Hukum dibentuk untuk menanggulangi wabah yang ada, namun persoalan teknis penegakan hukum sering kali terjadi. Contohnya Pasal 93 UU Kekarantinaan Kesehatan yang mengatur bahwa setiap orang yang tidak mematuhi penyelenggaraan Kekarantinaan Kesehatan sebagaimana dimaksud dalam Pasal 9 ayat (1) dan/atau menghalang-halangi penyelenggaraan Kekarantinaan Kesehatan sehingga menyebabkan Kedaruratan Kesehatan Masyarakat dipidana dengan pidana penjara paling lama 1 (satu) tahun dan/atau pidana denda paling banyak Rp.100.000.000,00 (seratus juta rupiah).

Merujuk ketentuan tersebut, maka terdapat dua perbuatan beserta sanksi pidana yang diatur di dalamnya. Pertama, yaitu tindakan "tidak mematuhi" ketentuan Pasal 9 ayat (1) UU Kekarantinaan Kesehatan. ${ }^{3}$ Kedua, yaitu tindakan "menghalang-halangi penyelenggaraan kekarantinaan kesehatan yang menyebabkan kedaruratan kesehatan". Namun, dalam tafsir teks hukum Code Penal Prancis yang berbunyi la loi poenale est d'interpretation stricte (hukum pidana harus ditafsirkan secara sempit). ${ }^{4}$ Kemudian hal tersebut juga berkenaan dengan penafsiran undang-undang titulus est lex est rubrica est lex (judul peraturan perundang-undangan dan

${ }^{1}$ Kompas.com, "WHO Resmi Sebut Virus Corona Covid-19 Sebagai Pandemi Global",24 Juni 2020. Tersedia online https://www.kompas.com/sains/read/ 2020/03/12/083129823/who-resmi-sebut-virus-corona-covid-19-sebagai-pandemiglobal?page=all.

${ }^{2}$ Covid19.go.id, "Peta Sebaran", 13 November 2020. Tersedia online https://covid19.go.id/peta-sebaran.

${ }^{3}$ Pasal 9 ayat (1) UU Kekarantinaan Kesehatan: "Setiap orang wajib mematuhi penyelenggaraan Kekarantinaan Kesehatan”.

${ }^{4}$ J. Remmelink, Pengantar Hukum Pidana Material 1, (Terjemahan Tristam P. Meliono), Yogyakarta: Maharsa, (2014), hlm. 53. 
bab peraturan perundang-undangan yang menentukan). ${ }^{5}$ Sehingga dapat diketahui bahwa Pasal 93 UU Kekarantinaan Kesehatan sudah mencakup segala upaya kekarantinaan kesehatan termasuk Pembatasan Sosial Berskala Besar (PSBB).

Ketidakjelasan ketentuan pidana UU Kekarantinaan Kesehatan bukan hanya pada aspek penentuan pelaku tindak pidananya saja, melainkan juga berkenaan dengan kausalitas pidana. Akibat hukum atas suatu perbuatan pidana dapat terjadi jika ada sebabnya (causal verband $)^{6}$. Hal ini bisa dilihat dalam ketentuan UU Kekarantinaan Kesehatan yang menempatkan "kedaruratan kesehatan" sebagai bagian dari "sebab", sedangkan kedaruratan kesehatan masyarakat dalam konteks hukum pidana dipandang sebagai sebuah "akibat" atas suatu perbuatan. Jika konteksnya demikian, maka akan sulit menentukan kapan dan kepada siapa pasal tersebut akan diterapkan. Mengingat kedaruratan kesehatan masyarakat sudah terjadi sebelumnya dan hal tersebut ditetapkan oleh Presiden. Jika dalam Pasal 93 UU Kekarantinaan Kesehatan mengatur dan mengharuskan ada akibat (materiele delicten) yang ditimbulkan atas perbuatan pidana sehingga terjadi kedaruratan kesehatan, maka pasal tersebut akan mengalami kesulitan dalam penegakannya. Karena kausalitas pidananya sulit dipenuhi atau bahkan tidak akan pernah terpenuhi sama sekali.

Melihat keadaan tersebut, maka akan menimbulkan pertanyaan bagaimana ketentuan pidana UU Kekarantinaan Kesehatan dapat dilaksanakan? Serta bagaimana kesesuaian antara kausalitas pidana dengan ketentuan pasal tersebut?. Bahkan dapat menghasilkan preskriptif hukum yang baru mengenai teori pemidanaan yang berkaitan dengan kebijakan hukum pidana bagi pelaku tindak pidana kekarantinaan kesehatan. Berdasarkan uraian permasalahan di atas, maka perlu pengkajian terhadap ketentuan pidana dalam UU Kekarantinaan Kesehatan dalam masa Pandemi Covid-19 sehingga penegakan hukum dapat dilaksanakan secara tegas dan tepat dan kesehatan notaris Indonesia tetap terjaga.

\section{${ }^{5}$ Ibid.}

${ }^{6}$ Causal Verband merupakan suatu doktrin penting untuk mengetahui relasi antara perbuatan atau beberapa perbuatan yang menjadi penyebab munculnya akibat. Lihat, Ahmad Sofian, Ajaran Kausalitas Hukum Pidana, Cet. II, Jakarta: Kencana Prenadamedia Group, (2018), hlm. 7. 
TELAAH KETENTUAN PIDANA KEKARANTINAAN KESEHATAN BERDASARKAN UNDANGUNDANG NOMOR 6 TAHUN 2018 BAGI KESEHATAN NOTARIS DAN MASYARAKAT ERA PANDEMI COVID-19 (M. Aris Munandar, Audyna Mayasari Muin, Hijrah Adhyanti Mirzana)

\section{METODE PENELITIAN}

\section{Jenis Penelitian}

Penelitian hukum (rectsonderzoek) merupakan suatu kegiatan knowhow yang dilakukan untuk memecahkan isu hukum yang dihadapi. ${ }^{7}$ Penelitian hukum (rectsonderzoek) adalah suatu proses untuk menemukan aturan hukum, prinsip-prinsip hukum, maupun doktrin-doktrin hukum guna menjawab isu hukum yang dihadapi. ${ }^{8}$ Di dalam penelitian ini menggunakan jenis penelitian hukum normatif atau doktrinal. Menurut Terry Hutchinson ${ }^{9}$ pengertian penelitian hukum doktrinal adalah:

"Doctrinal research: research wich provides a systematic exposition of the rules governing a particular legal category, analyses the relationship between rules, explain areas of difficulty and, perhaps, predicts future development."

Sedangkan menurut Peter Mahmud Marzuki ${ }^{10}$ disebut sebagai penelitian hukum normatif karena jenis penelitian tersebut dilakukan dengan cara menganalisis norma-norma hukum (ketentuan-ketentuan yang ada). Penelitian ini juga merupakan penelitian yang membahas secara sistematis, menganalisis hubungan antara ketentuan-ketentuan, dan mengkaji serta memperkirakan kemungkinan perkembangan di masa yang akan datang. Penelitian ini memiliki objek penelitian yaitu norma-norma, konsep hukum, asas hukum, dan doktrin hukum. ${ }^{11}$ Dengan demikian, penelitian ini lebih menitikberatkan pada penelitian kepustakaan (literature research), artinya lebih dominan mengkaji bahan hukum sekunder yang dihasilkan dari penelitian.

\section{Pendekatan Penelitian}

Berdasarkan rumusan masalah dan tujuan penelitian yang telah dijabarkan tersebut, maka metode pendekatan yang digunakan dalam penelitian ini ialah pendekatan perundang-undangan (statute approach). Dalam pendekatan perundang-undangan peneliti melakukan telaah terhadap undang-undang serta regulasi yang berkaitan dengan isu hukum yang dikaji,

${ }^{7}$ Peter Mahmud Marzuki, Penelitian Hukum (Edisi Revisi), Kencana Prenadamedia Group, Jakarta, 2017, hlm. 60.

${ }^{8}$ Peter Mahmud Marzuki, Penelitian Hukum, Kencana Prenada Media Group, Jakarta, 2010, hlm. 35.

${ }^{9}$ Ibid., hlm. 32.

${ }^{10}$ Agus Yudha Handoko, Hukum Perjanjian Asas Proporsionalitas dalam Kontrak Komersial, Kencana Prenadamedia Group, Jakarta, 2010, hlm. 38.

${ }^{11}$ I Made Pasek Diantha, Metodologi Penelitian Hukum Normatif dalam Justifikasi Teori Hukum, Kencana Prenadamedia Group, Jakarta, 2017, hlm. 2. 
serta mencari ratio legis dan dasar ontologis lahirnya sebuah undangundang. ${ }^{12}$

\section{Jenis dan Sumber Bahan Hukum}

Jenis dan sumber bahan hukum yang digunakan pada penelitian ini adalah bahan yang mempunyai kaitan dengan permasalahan serta tujuan dari penelitian tersebut. Adapun yang menjadi bahan hukum yang digunakan, antara lain:

\section{a. Bahan Hukum Primer}

Bahan hukum primer merupakan bahan hukum yang bersifat otoritatif, dalam artian memiliki otoritas. Bahan hukum primer tersebut terdiri dari perundang-undangan, catatan-catatan resmi atau risalah dalam pembuatan undang-undang dan putusan-putusan hakim. ${ }^{13}$ Adapun bahan hukum primer dalam penelitian ini, antara lain:

1) Undang-Undang Republik Indonesia Nomor 6 Tahun 2018 tentang Kekarantinaan Kesehatan;

2) Peraturan Pemerintah Republik Indonesia Nomor 21 Tahun 2020 Tentang Pembatasan Sosial Berskala Besar dalam Rangka Percepatan Penanganan Coronavirus Disease 2019 (Covid-19);

3) Putusan Pengadilan Negeri Makassar No. 43/Pid.S/2020/PN.Mks;

4) Putusan Pengadilan Negeri Makassar No. 47/Pid.S/2020/PN.Mks.

b. Bahan Hukum Sekunder

Bahan hukum sekunder yakni seluruh publikasi tentang hukum yang bukan merupakan dokumen-dokumen resmi. Publikasi tentang hukum meliputi buku-buku teks, kamus-kamus hukum, jurnal-jurnal hukum, dan komentar-komentar atas suatu putusan pengadilan yang berkaitan erat dengan masalah yang sedang dikaji. ${ }^{14}$

\section{c. Bahan Non-Hukum}

Bahan non-hukum berupa buku-buku mengenai ilmu politik, ekonomi, sosiologi, filsafat, kebudayaan ataupun laporan-laporan penelitian non-hukum dan jurnal-jurnal non-hukum sepanjang mempunyai korelasi dan relevansi dengan topik yang sedang diteliti. ${ }^{15}$

\section{Proses Pengumpulan Bahan Hukum}

Berdasarkan jenis penelitian dan sumber bahan hukum yang digunakan dalam penulisan karya ilmiah ini, maka pengumpulan bahan hukumnya meliputi:

\footnotetext{
${ }^{12}$ Peter Mahmud Marzuki, 2017, Op.Cit., hlm. 133-134.

${ }^{13}$ Ibid., hlm. 181.

${ }^{14}$ Ibid.

${ }^{15}$ Ibid., hlm. 183-184.
} 
TELAAH KETENTUAN PIDANA KEKARANTINAAN KESEHATAN BERDASARKAN UNDANGUNDANG NOMOR 6 TAHUN 2018 BAGI KESEHATAN NOTARIS DAN MASYARAKAT ERA PANDEMI COVID-19 (M. Aris Munandar, Audyna Mayasari Muin, Hijrah Adhyanti Mirzana)

\section{a. Proses Pengumpulan Bahan Hukum Primer}

Proses pengumpulan bahan hukum ini menggunakan pendekatan perundang-undangan (statute approach). Adapun yang harus dilakukan adalah menelusuri dan mencari peraturan perundang-undangan mengenai atau yang berkaitan dengan isu yang sedang dikaji. Peraturan perundangundangan yang dimaksud adalah berupa legislation maupun regulation termasuk juga delegated legislation dan delegated regulation. ${ }^{16}$

\section{b. Proses Pengumpulan Bahan Hukum Sekunder}

Pada proses ini, yang seyogianya dilakukan ialah penelusuran dengan menggunakan studi kepustakaan terhadap publikasi terkait hukum yang bukan merupakan dokumen sifatnya resmi tetapi masih memiliki korelasi dengan permasalahan yang akan diteliti tersebut.

\section{c. Proses Pengumpulan Bahan Non-Hukum}

Pada proses ini, yang dilakukan adalah mengumpulkan dan menelusuri seluruh bahan-bahan di luar bidang hukum yang sifatnya memberikan penjelasan dan petunjuk terhadap bahan hukum primer dan sekunder serta memiliki korelasi dengan permasalahan yang menjadi kajian yang sedang diteliti.

\section{Analisis Bahan Hukum}

Setelah semua bahan hukum diperoleh baik primer, sekunder, maupun bahan non-hukum, selanjutnya diidentifikasi dan diinventarisasi. Kemudian bahan hukum dianalisis menggunakan pendekatan perundangundangan (statute approach) agar mendapatkan gambaran yang sistematis dan kompleks dari seluruh jenis bahan hukum dengan proses analisis kualitatif yang mendeskripsikan bahan hukum ke dalam bentuk kalimat yang sederhana dan logis, serta diberi penafsiran dan kesimpulan. Analisis tersebut bertujuan untuk menghasilkan preskripsi atau pendapat hukum yang baru dan mampu memecahkan setiap permasalahan hukum.

\section{PEMBAHASAN}

Kekarantinaan kesehatan adalah upaya mencegah dan menangkal keluar atau masuknya penyakit dan/atau faktor risiko kesehatan masyarakat yang berpotensi menimbulkan kedaruratan kesehatan masyarakat. (Vide: Pasal 1 angka (1) UU Kekarantinaan Kesehatan). Secara expressis verbis, pasal tersebut menjelaskan bahwa upaya penanggulangan suatu wabah dengan menyelenggarakan kekarantinaan kesehatan. Secara politis, kebijakan ini dibentuk untuk memenuhi salah satu hak warga negara Indonesia, yakni hak atas kesehatan (Right to Health). Hak tersebut secara konstitusional diatur dalam Pasal 28H ayat (1) Undang-Undang Dasar

${ }^{16}$ Ibid., hlm. 237. 
Negara Republik Indonesia Tahun 1945 (UUD NRI 1945) yang berbunyi: "Setiap orang berhak hidup sejahtera lahir dan batin, bertempat tinggal, dan mendapatkan lingkungan hidup yang baik dan sehat serta berhak memperoleh pelayanan kesehatan". Lebih lanjut diatur dalam Pasal 9 ayat (3) Undang-Undang Nomor 39 Tahun 1999 tentang Hak Asasi Manusia (UU HAM), bahwa: "Setiap orang berhak atas lingkungan hidup yang baik dan sehat". Oleh karena itu, diperlukan akses pemenuhan hak melalui penyelenggaraan kekarantinaan kesehatan di masa pandemi Covid-19.

Hukum sebagai alat kontrol sosial (law as a tool of social engineering) sebagaimana yang dikemukakan oleh Roscoe Pond yang berarti hukum sebagai alat pembaharuan dalam masyarakat, dalam istilah ini hukum diharapkan dapat berperan merubah nilai-nilai sosial dalam masyarakat. Hukum harus menjadi pelindung masyarakat atas suatu tindak pidana, yang dimulai upayanya dari proses perumusan ketentuan pidana undang-undang, serta kalkulasi implikasi hukum atas pengaturan sektor kehidupan masyarakat, khususnya sektor kesehatan. Hal tersebut dilakukan sebagai upaya mencapai kebijakan hukum pidana yang tidak mengandung kekaburan dan ketidakpastian yang berdampak pada penegakan hukum.

Selama pandemi Covid-19 di Indonesia yang pertama kali ditemukan pada Maret 2020, Pemerintah dan jajarannya telah mengupayakan penanganan secara yuridis. Terdapat beberapa aturan hukum yang dihasilkan, misalnya Peraturan Presiden Nomor 21 Tahun 2020 tentang Pembatasan Sosial Berskala Besar (PSBB) dalam Rangka Percepatan Penanganan Covid-19 2019. Aturan tersebut menjadi acuan bagi setiap Pemerintah Daerah (kabupaten/kota dan provinsi) dalam rangka menangani Covid-19. PSBB sendiri merupakan salah satu upaya kekarantinaan kesehatan yang diatur dalam Pasal 15 ayat (2) UU Kekarantinaan Kesehatan.

Penanganan Covid-19 melalui tindakan kekarantinaan kesehatan secara sederhana dianggap sebagai sebuah solusi. Namun, perlu dianalisis terkait pengaturan sanksi pidana dalam UU Kekarantinaan Kesehatan. Hukum harus dapat diterapkan serta mempunyai dampak yang jelas di masyarakat, seperti tujuan hukum, yaitu kepastian, keadilan, dan kemanfaatan. Jika hukumnya mengalami ketidakpastian, maka penerapannya juga akan demikian.

\section{Urgensi Asas Legalitas dalam Rumusan Tindak Pidana}

Asas legalitas pada awalnya dipelopori oleh Paul Johan Anslem von Feurbach (1775-1833). Rumusan kalimat dalam asas legalitas yakni: "nulla poena sine lege; nulla poena sine crimine; nullum crimen sine poena legali". Selanjutnya ketiga kalimat tersebut menjadi sebuah adagium yang 
TELAAH KETENTUAN PIDANA KEKARANTINAAN KESEHATAN BERDASARKAN UNDANGUNDANG NOMOR 6 TAHUN 2018 BAGI KESEHATAN NOTARIS DAN MASYARAKAT ERA PANDEMI COVID-19 (M. Aris Munandar, Audyna Mayasari Muin, Hijrah Adhyanti Mirzana) berbunyi: "nullum delictum, nulla poena sine praevia legi poenali" yang hingga saat ini digunakan oleh para Sarjana Hukum. ${ }^{17}$

Asas legalitas dalam ajaran von Feurbach pada dasarnya menginginkan penjeraan akan tetapi tidak dengan penerapan pidana, melainkan dengan ancaman pidana dalam peraturan perundang-undangan. Sehingga mesti dicantumkan secara expressis verbis kejahatan maupun pidananya (psychologische dwang). ${ }^{18}$ Dalam artian, dalam hal menentukan perbuatan yang dilarang pada suatu peraturan pidana, bukan hanya perbuatan dituliskan secara konkret (jelas) dalam perundang-undangan, akan tetapi juga terkait jenis delik yang diancamkan. Hasilnya, orang yang hendak melakukan sebuah tindak pidana telah mengetahui terlebih dahulu mengenai pidana yang diancamkan dalam undang-undang. ${ }^{19}$ van der Donk ${ }^{20}$ menguraikan bahwasanya maksud dari ajaran von Feurbach tersebut adalah untuk memberikan limitasi hasrat atau niat seseorang untuk melakukan sebuah kejahatan.

Secara detail Machteid Boot $^{21}$ menguraikan beberapa hal yang berkenaan dengan asas legalitas, yaitu:

a. Prinsip "nullum crimen, noela poena sine lege praevia" artinya tidak ada perbuatan pidana, tidak ada pidana tanpa undang-undang sebelumnya. Impaknya adalah ketentuan hukum pidana tidak boleh berlaku surut. Dalam perkembangannya makna tersebut telah disimpangi oleh beberapa negara dengan asumsi melindungi kepentingan negara dan baha yang ditimbulkan bagi khalayak sosial;

b. Prinsip "nullum cimen, nulla poena sine lege scripta" bermakna tidak ada perbuatan pidana, tidak ada pidana tanpa undang-undang yang tertulis. Impaknya adalah seluruh ketentuan pidana haruslah tertulis. Dalam artian baik perbuatan yang dilarang, juga pidana yang diancamkan terhadap suatu perbuatan yang dilarang harus tertulis jelas dan terang dalam peraturan perundang-undangan;

${ }^{17}$ Eddy O.S. Hiariej, Asas Legalitas dan Perkembangannya dalam Hukum Pidana, Makalah Pelatihan Hukum Pidana dan Kriminologi, 23-27 Februari 2014, Yogyakarta, hlm. 1. Lihat juga, Amir Ilyas dan Muhammad Nursal, Kumpulan Asas-Asas Hukum, PT RajaGrafindo Persada, Jakarta, 2016, hlm. 9.

${ }^{18}$ Ibid., hlm. 3. Lihat juga, Ch. J., Enschede, Beginselen Van Strafrecht, Kluwer, Deventer 2002, hlm. 26.

${ }^{19}$ Ibid. Lihat juga, Moeljatno, Asas-Asas Hukum Pidana, Rineka Cipta, Jakarta, 2000, hlm. 25.

${ }^{20}$ Ibid. Lihat juga, E. Utrecht, Hukum Pidana 1, Penerbitan Universitas, Bandung, 1960, hlm. 195.

${ }^{21}$ Eddy O.S. Hiariej, Op.Cit., hlm. 10-11. 
c. Prinsip "nullum crimen, nulla poena sine lege certa" berarti tidak ada suatu perbuatan pidana, tidak ada pidana tanpa aturan undang-undang yang jelas. Impaknya adalah bahwasanya rumusan perbuatan pidana mestilah jelas sehingga tidak bersifat multi tafsir yang bisa berbahaya bagi kepastian hukum sebagai tujuan hukum. Selain itu, juga berbahaya dalam penuntutan oleh Jaksa Penuntut Umum (JPU), dengan rumusan yang jelas JPU akan dengan mudah menentukan perbyatan mana yang dikualifikasikan sebagai perbuatan pidana dan yang bukan; dan

d. Prinsip "nullum crimen, noela poena sine lege stricta" bermakna bahwa tidak ada perbuatan pidana, tidak ada pidana tanpa undang-undang yang ketat. Impaknya adalah secara eksplisit melarang penggunaan analogi. Dalam artian ketentuan pidana haruslah ditafsirkan secara ketat agar tidak menimbulkan perbuatan pidana yang baru.

Jika melihat penjelasan di atas, maka menurut penulis ada dua makna penting dari asas legalitas dalam merumuskan suatu tindak pidana. Pertama, yaitu suatu undang-undang haruslah ditafsirkan secara ketat (lex stricta). Konsekuensi logis dari anggapan tersebut ialah bahwa undangundang patut ditafsirkan terbatas dan tidak boleh menggunakan analogi liberal. Agar tercapai kepastian hukum. Kedua, makna penting dari asas legalitas lainnya yakni undang-undang harus dirumuskan secara jelas (lex certa) dan tidak ambigu. Bahwasanya rumusan delik dalam suatu ketentuan pidana sepantasnya jelas agar tidak menimbulkan ketidakpastian hukum dan berpotensi untuk ditafsirkan secara luas. Hal tersebut juga akan menguntungkan penegak hukum serta menjadi legasi dan preseden yang baik dalam pembentukan hukum di Indonesia khususnya.

Pembentukan hukum dengan mengedepankan prinsip asas legalitas rumusan delik merupakan perwujudan bentuk dari asas legalitas sebagaimana dalam Pasal 1 ayat (1) KUHP. Dalam konteks pembuktian, menurut Eddy O.S. Hiariej22 dalam Asep Suherman, mengemukakan bahwasanya rumusan delik dalam suatu peraturan perundang-undangan selain merupakan wujud dari asas legalitas, juga mempunyai fungsi sebagai unjuk bukti. Dalam artian, yang wajib dibuktikan oleh JPU adalah unsur tindak pidana dalam suatu rumusan ketentuan pidana yang didakwakan kepada tersangka di pengadilan.

Unjuk bukti dapat dipahami sebagai upaya dari pembentuk undangundang untuk mengkristalisasi suatu tata nilai masyarakat menjadi sebuah

${ }^{22}$ Asep Suherman, Esensi Asas Legalitas dalam Penegakan Hukum Pidana Lingkungan, Jurnal Bina Hukum Lingkungan, Vol. 5, No. 1, 2020, hlm. 149. Lihat juga, Eddy O.S. Hiariej, Teori dan Hukum Pembuktian, Erlangga, Jakarta, 2012, hlm. 37. 
standar etis di dalam undang-undang pidana. Korelasi antara substansi dan penerapan hukum tersebut menjadi kekuatan dalam menegakkan kepastian hukum yang fondasinya berasal dari prinsip asas legalitas sebagaimana yang telah dijelaskan sebelumnya. Maka, pembuktian secara empiris di pengadilan adalah wujud nyata dari esensialitas asas legalitas sebagai postulat hukum yang selama ini diagung-agungkan oleh negara hukum.

Asas legalitas wajib dipahami sebagai unsur penting dalam hukum sistem hukum. Bahwasanya dalam sistem hukum jelas menjabarkan tiga hal, yakni substansi hukum, struktur hukum, dan budaya hukum. Substansi hukum atau rumusan pasal dalam undang-undang menjadi subsistem utama dalam sistem hukum karena buruk atau tidaknya substansi hukum akan memengaruhi struktur hukum dan budaya hukum. Seperti yang diketahui, budaya hukum menjadi salah satu faktor penegakan hukum di samping undang-undang sebagai faktor utama. Olehnya itu, ketika substansi hukum bermasalah akan berimplikasi pada subsistem hukum lainnya.

\section{Kebijakan Hukum Pidana (Penal Policy) Kegiatan Merintangi Penyelenggaraan Kekarantinaan Kesehatan \\ a. Problematika Penggunaan Frasa dalam Rumusan Pasal 93 Undang- Undang Nomor 6 Tahun 2018 Tentang Kekarantinaan Kesehatan}

Kebijakan hukum pidana (penal policy) merupakan pengaturan sanksi pidana atas suatu perbuatan yang sebelumnya telah dianggap sebagai tindak pidana atau kriminalisasi yang membahas soal idealistis suatu sanksi pidana atas peraturan perundang-undangan pidana, dalam hal ini UU Kekarantinaan Kesehatan. Menurut Ivo Lapenna ${ }^{23}$ (University of London) kebijakan hukum pidana, yaitu "is a part of the general policy of a society .... aimed at combating crime, and it embraces all methods and measures applied for this purpose. All these remedies against crime may be divided into two main groups: measures of prevention and measures of repression". Ivo Lapenna memaknai kebijakan hukum pidana sebagai "bagian dari kebijakan umum masyarakat yang bertujuan untuk memerangi kejahatan dan mencakup semua cara serta tindakan yang diterapkan untuk mencapai tujuan itu. Solusi dalam menangani kejahatan tersebut dibagi menjadi dua kelompok, yaitu tindakan pencegahan dan penindakan secara represif".

${ }^{23}$ Pujiyono dan Ade Adhari, Hukum Pidana di Bidang Sumber Daya Alam, Yogyakarta: Deepublish, (2019), hlm. 163. Lihat juga, Ivo Lapenna, Soviet Penal Policy, WC2 by William Clowes \& Sons Ltd, Bow Street London: Beccels Set in Monotype Plantin First Published in (1968). Republished by www.kehlet.com and Birthe Lapenna in Denmark, (Desember 2000), hlm. 10. 
Marc Ancel $^{24}$ memberikan uraian bahwa dalam modern criminal science terdiri atas tiga komponen, yakni "criminology", "criminal law", dan "penal policy". Menurutnya, kebijakan hukum pidana (penal policy) merupakan ilmu sekaligus seni yang memiliki tujuan praktis dalam memberikan rumusan undang-undang, menerapkan undang-undang serta melaksanakan suatu putusan pengadilan. Menurut Barda Nawawi Arief ${ }^{25}$ dalam bukunya mengemukakan, bahwa:

"Kebijakan hukum pidana merupakan terjemahan langsung dari istilah penal policy, namun adakalanya istilah penal policy ini diterjemahkan pula dengan politik hukum pidana. Istilah penal policy ini mempunyai pengertian yang sama dengan istilah criminal law policy dan strafrechts politiek sehingga kedua istilah ini juga diterjemahkan dengan politik hukum pidana atau kebijakan hukum pidana, akan tetapi dari penjelasan sebelumnya bahwa istilah kebijakan diambil dari istilah policy dalam bahasa Inggris atau Politiek dalam bahasa Belanda."

Berdasarkan uraian di atas, maka dapat diketahui bahwa kebijakan hukum pidana (penal policy) dapat diartikan sebagai segala usaha dalam mencapai peraturan perundang-undangan pidana yang sesuai dengan situasi dan kondisi pada waktu tertentu baik untuk saat ini (ius constitutum) maupun untuk masa yang akan datang (ius constituendum). Selain itu, kebijakan hukum pidana juga berkaitan erat dan menjadi bagian dari kebijakan kriminalisasi dalam konteks pembaharuan hukum pidana.

UU Kekarantinaan Kesehatan dibentuk atas dasar pertimbangan kemajuan teknologi transportasi dan era perdagangan bebas yang berisiko dapat menimbulkan gangguan kesehatan dan penyakit baru atau penyakit lama dengan penyebaran yang lebih cepat dan berpotensi menimbulkan kedaruratan kesehatan masyarakat, sehingga menuntut adanya upaya pencegahan penyakit dan faktor risiko kesehatan yang komprehensif dan terkoordinasi, serta membutuhkan sumber daya, peran serta masyarakat, dan kerja sama internasional (Vide: Huruf b Konsideran Menimbang UU Kekarantinaan Kesehatan). Diterbitkannya UU Kekarantinaan Kesehatan mengakibatkan dicabutnya Undang-Undang Nomor 1 Tahun 1962 tentang Karantina Laut dan Undang-Undang Nomor 2 Tahun 1962 tentang

${ }^{24}$ John Kenedi, "Kebijakan Kriminal (Criminal Policy) dalam Negara Hukum Indonesia: Upaya Mensejahterakan Masyarakat (Social Welfare)", Jurnal Pemerintahan dan Politik Islam: Al-Imarah 2, No. 1 (2017): 15-26, hlm. 20. Lihat juga, Barda Nawawi Arief, Bunga Rampai Kebijakan Hukum Pidana, Bandung: PT. Citra Aditya Bakti, (1996), hlm. 23.

${ }^{25}$ Ibid., Lihat juga, Barda Nawawi Arief, Ibid., hlm. 26. 
TELAAH KETENTUAN PIDANA KEKARANTINAAN KESEHATAN BERDASARKAN UNDANGUNDANG NOMOR 6 TAHUN 2018 BAGI KESEHATAN NOTARIS DAN MASYARAKAT ERA PANDEMI COVID-19 (M. Aris Munandar, Audyna Mayasari Muin, Hijrah Adhyanti Mirzana) Karantina Udara karena dianggap tidak sesuai lagi dengan perkembangan, tuntutan, dan kebutuhan hukum dalam masyarakat.

Pengaturan mengenai tindak pidana kekarantinaan kesehatan diatur pada Pasal 90 hingga Pasal 94. Pada Pasal 93 memunculkan kontroversi di masyarakat. Dalam pasal a quo, secara jelas dan terang diatur suatu ketentuan mengenai ketentuan pidana bagi pelanggar penyelenggaraan kekarantinaan kesehatan dengan membaginya ke dalam dua jenis delik. Pada bagian pertama diatur bahwa "Setiap orang yang tidak mematuhi penyelenggaraan Kekarantinaan Kesehatan sebagaimana dimaksud dalam Pasal 9 ayat (1)". Unsur pertama Pasal 93 UU Kekarantinaan Kesehatan ini merupakan delik formil yang menyaratkan sebuah tindak pidana dinilai dari aspek perbuatan. ${ }^{26}$

Kedua, diatur bahwa “....menghalang-halangi penyelenggaraan Kekarantinaan Kesehatan sehingga menyebabkan Kedaruratan Kesehatan Masyarakat dipidana dengan pidana penjara paling lama 1 (satu) tahun dan/atau pidana denda paling banyak Rp.100.000.000,00 (seratus juta rupiah)". Unsur kedua dari ketentuan tersebut merupakan delik materiel yang menitikberatkan penilaian suatu tindak pidana pada aspek akibat yang ditimbulkan oleh suatu perbuatan (sebab). ${ }^{27}$

Istilah "mengahalang-halangi" tersebut mengalami kekaburan (obscuur libel) dan menimbulkan penafsiran yang liberal. Hal ini bertentangan dengan asas kejelasan rumusan yang diatur dalam UndangUndang Nomor 12 Tahun 2011 tentang Pembentukan Peraturan PerundangUndangan sebagaimana telah diubah dalam Undang-Undang Nomor 15 Tahun 2019 tentang Perubahan Atas Undang-Undang Nomor 12 Tahun 2011 tentang Pembentukan Peraturan Perundang-Undangan, yang secara expressis verbis berbunyi bahwa dalam membentuk peraturan perundangundangan harus dilakukan berdasarkan pada asas pembentukan peraturan perundang-undangan yang baik meliputi asas kejelasan rumusan.

Pembentuk undang-undang tidak memberikan penjelasan secara detail terkait definisi "menghalang-halangi" pada pasal a quo, sehingga akan berimplikasi pada penerapan dan penegakan hukum di masyarakat. Hal ini bersesuaian ketentuan pidana Pasal 21 Undang-Undang Nomor 31 Tahun 1999 tentang Pemberantasan Tindak Pidana Korupsi sebagaimana telah diubah dengan Undang-Undang Nomor 20 Tahun 2001 tentang Perubahan Atas Undang-Undang Nomor 31 Tahun 1999 tentang Pemberantasan Tindak Pidana Korupsi (UU PTPK), bahwa pada Pasal 21 UU PTPK

${ }^{26}$ Andi Sofyan dan Nur Azisa, Buku Ajar Hukum Pidana, Makassar: Pustaka Pena Pers, (2016), hlm. 105. Lihat juga, Sofjan Sastrawidjaja, Hukum Pidana 1, Bandung: CV. Armico, (1990), hlm. 135.

${ }^{27}$ Ibid. 
memuat unsur yang hampir sama dengan frasa "merintangi". Dalam UU PTPK juga tidak dijelaskan secara jelas apa yang dimaksud dengan perbuatan "merintangi". Pasal 21 UU PTPK tersebut telah berulang kali dilakukan pengujian ke Mahkamah Konstitusi, hal ini mengindikasikan bahwa pasal yang memuat frasa "Menghalang-halangi" tersebut mengalami persoalan di lapangan. Perlu diketahui, dalam KBBI istilah merintangi sama dengan pengertian menghalang-halangi. Oleh karena itu, pasal a quo bisa menimbulkan obstruction of justice dan ketidakpastian hukum.

Permasalahan selanjutnya adalah terdapat pada frasa "Menyebabkan Kedaruratan Kesehatan Masyarakat". Jika menelisik pasal a quo, maka muncul sebuah pandangan hukum bahwa dengan menempatkan frasa "Menyebabkan" pada rumusan yang seyogianya merujuk dan menuju pada suatu "Akibat" yakni "Kedaruratan Kesehatan Masyarakat" merupakan kekeliruan dalam sebuah pembentukan hukum. Sebuah rumusan unsur tindak pidana sudah seharusnya memperhatikan aspek kausalitas pidana. Kausalitas (sebab-akibat) merupakan hubungan atau proses antara dua atau lebih kejadian atau keadaan dari peristiwa di mana satu faktor menimbulkan atau menyebabkan faktor lainnya. ${ }^{28}$

Penentuan sebab suatu akibat dalam hukum pidana merupakan suatu masalah yang sulit dipecahkan. Pada dasarnya dalam Pasal 93 UU Kekarantinaan Kesehatan juga mengandung delicta commisionis per ommisionem commisa, yakni delik dapat diwujudkan dengan perbuatan aktif maupun pasif, atau dengan perkataan lain delik terjadi karena adanya perbuatan (handeling) atau pengabaian (nalaten). ${ }^{29}$ Perbuatan aktif dalam Pasal 93 UU Kekarantinaan Kesehatan yakni perbuatan "Menghalanghalangi penyelenggaraan kekarantinaan kesehatan". Sedangkan perbuatan pasifnya, yakni "Tidak mematuhi penyelenggaraan kekarantinaan kesehatan".

Merujuk pada hal tersebut, maka dapat disimpulkan bahwasanya penggunaan frasa "Menyebabkan kedaruratan kesehatan masyarakat" tidak rasional dan tidak relevan dalam hukum pidana. Menurut peneliti bahwa istilah yang pantas digunakan adalah "Mengakibatkan" karena sebelumnya sudah ada sebuah perbuatan aktif, yakni "menghalang-halangi" sebagai (sebab). Pandangan tersebut bersesuaian dengan yang dikatakan oleh Traeger ${ }^{30}$ bahwa akibat delik haruslah in het algemeen voorzienbaar (pada umumnya dapat disadari sebagai sesuatu yang sangat mungkin terjadi). Hal

\footnotetext{
${ }^{28}$ Ahmad Sofian, Ajaran Kausalitas Pidana, Jakarta: Kencana Prenadamedia Group, (2018), hlm. 17-18.

${ }^{29}$ H. A. Zainal Abidin Farid, Hukum Pidana 1, Jakarta: Sinar Grafika, (2014), hlm. 214.

${ }^{30}$ H. Andi Zainal Abidin Farid, Op.Cit., hlm. 213.
} 
TELAAH KETENTUAN PIDANA KEKARANTINAAN KESEHATAN BERDASARKAN UNDANGUNDANG NOMOR 6 TAHUN 2018 BAGI KESEHATAN NOTARIS DAN MASYARAKAT ERA PANDEMI COVID-19 (M. Aris Munandar, Audyna Mayasari Muin, Hijrah Adhyanti Mirzana) serupa dikatakan oleh van Bemmelen ${ }^{31}$ bahwa yang dimaksud in het algemeen voorzienbaar adalah een hoge mate van waarschijnlijkheid (disadari sebagai sesuatu yang sangat mungkin dapat terjadi).

Terkait kekaburan suatu rumusan undang-undang, Matanggui ${ }^{32}$ mengemukakan bahwa:

"Hukum dan peraturan perundang-undangan mengatur berbagai dimensi kehidupan masyarakat. Agar tidak ada keraguan di dalamnya, kalimat yang digunakan harus benar isi dan strukturnya, baku, efektif, tidak bertele-tele, tidak berbelit-belit, tidak bersayap, dan tidak bermakna ganda. Makna kalimatnya harus jelas (clear), tidak samar (not vague), tidak taksa (tidak ambigu), dan isi informasinya harus benar sehingga tidak menyulitkan pemahaman dan penerapan hukum dan peraturan perundang-undangan itu sendiri."

Lebih lanjut dijelaskan oleh Hadikusumo dalam Hartini ${ }^{33}$ sebagaimana dikutip oleh Rati Riana dan Muhammad Junaidi dalam Jurnal Legislasi Indonesia, menyatakan bahwa:

"Bahasa hukum adalah bahasa aturan dan peraturan yang bertujuan untuk mewujudkan ketertiban dan keadilan untuk mempertahankan kepentingan umum dan kepentingan pribadi dalam masyarakat. Namun, karena bahasa hukum bagian dari bahasa Indonesia yang modern, maka dalam penggunaannya ia harus tetap, terang, monosentrik dan memenuhi syarat estetika bahasa Indonesia."

Berdasarkan hal tersebut, maka kedudukan subjek hukum dalam undang-undang sangatlah penting karena berkaitan erat dengan aspek kehidupan masyarakat. Selain itu, kejelasan suatu rumusan undang-undang dipandang sebagai bagian tak terpisahkan dari upaya mencapai kepastian hukum yang berdasarkan pada asas legalitas (nullum delictum nulla poena sine praevia lege poenale). Tidak dapat dipidana suatu perbuatan jika sebelumnya belum ada peraturan yang mengaturnya. Asas legalitas yang masih berlaku menyaratkan harus ada peraturan hukum pidana (strafrechtsnorm) dan peraturan pidana (strafnorm) lebih dahulu daripada perbuatan/peristiwa. ${ }^{34}$ Implikasi dari postulat hukum ini adalah setiap perbuatan baik yang disengaja maupun tidak disengaja (lalai), baik

${ }^{31}$ Ibid.

${ }^{32}$ Rati Riana dan Muhammad Junaidi, "Konstitusionalisasi Pembentukan Peraturan Perundang-Undangan Melalui Penggunaan Bahasa Indonesia Baku", Jurnal Legislasi $\begin{array}{llllll}\text { Indonesia } & 15, & \text { No. } & 4 & \text { (2018): } & 275-283\end{array}$ jurnal.peraturan.go.id/index.php/jli/article/view/261. hlm. 276.

${ }^{33}$ Ibid., hlm. 277. Lihat juga, Lilis Hartini, Bahasa dan Produk Hukum, Bandung: Refika Aditama, (2014), hlm. 15.

${ }^{34}$ H. A. Zainal Abidin Farid, Op.Cit., hlm. 132. 
kejahatan maupun pelanggaran, secara hukum positif haruslah diatur terlebih dahulu agar memiliki kekuatan hukum untuk menerapkan sanksi. Peraturan yang baik dan jelas tentunya akan menghasilkan penerapan hukum yang tepat dan efektif.

Oleh karena itu, suatu undang-undang yang terikat asas legalitas tidak boleh mengandung rumusan pasal yang abstrak dan mengundang penafsiran secara analogi. Sebagaimana dikemukakan oleh H. A. Zainal Abidin Farid ${ }^{35}$ bahwa penafsiran analogi sama dengan penafsiran ekstensif, sehingga keduanya bertentangan dengan Pasal 1 ayat (1) Kitab UndangUndang Hukum Pidana (KUHP): "Suatu perbuatan tidak dapat dipidana, kecuali berdasarkan kekuatan ketentuan peraturan perundang-undangan pidana yang telah ada", karena bukan lagi penafsiran dalam ilmu hukum pidana. Sederhananya, rumusan pasal yang bertentangan dengan asas legalitas (kepastian hukum) akan membuka peluang digunakannya penafsiran analogi/ekstensif.

Frasa "menghalang-halangi" dalam Pasal 93 UU Kekarantinaan Kesehatan akan membuka celah bagi penegak hukum untuk menggunakan analogi sebagai sebuah penafsiran, khususnya bagi hakim. Hal ini dikarenakan tidak adanya batasan definisi yang jelas dalam UU Kekarantinaan Kesehatan terkait frasa "menghalang-halangi".

Jika menggunakan teori kebijakan hukum pidana (penal policy), maka sekiranya bisa disimpulkan bahwa ketentuan pidana UU Kekarantinaan Kesehatan tidak sesuai dengan keadaan dan situasi yang terjadi pada saat ini. Serta peraturan ini sangat sulit untuk digunakan atau diterapkan. Sebagaimana yang diungkapkan oleh Sudarto, ${ }^{36}$ bahwa kebijakan atau politik hukum pidana yaitu:

a. Usaha untuk mewujudkan peraturan-peraturan yang baik sesuai dengan keadaan dan situasi pada saat itu;

b. Kebijakan dari negara melalui badan-badan yang berwenang untuk menetapkan peraturan-peraturan yang dikehendaki yang diperkirakan bisa digunakan untuk mengekspresikan apa yang terkandung dalam masyarakat dana untuk mencapai apa yang diharapkan.

\section{b. Pelibatan Masyarakat dalam Penyelenggaraan Kekarantinaan Kesehatan}

UU Kekarantinaan Kesehatan dijadikan sebagai instrumen penanganan peristiwa bencana non alam berupa kedaruratan kesehatan masyarakat. Sebagaimana dijelaskan dalam Pasal 1 angka (1) UU

\footnotetext{
${ }^{35}$ Ibid. hlm. 124.

${ }^{36}$ John Kenedi, Op.Cit., hlm. 21. Lihat juga, Barda Nawawi Arief, Op.Cit., hlm. 24.
} 
TELAAH KETENTUAN PIDANA KEKARANTINAAN KESEHATAN BERDASARKAN UNDANGUNDANG NOMOR 6 TAHUN 2018 BAGI KESEHATAN NOTARIS DAN MASYARAKAT ERA PANDEMI COVID-19 (M. Aris Munandar, Audyna Mayasari Muin, Hijrah Adhyanti Mirzana) Kekarantinaan Kesehatan, yang berbunyi: "Kekarantinaan Kesehatan adalah upaya mencegah dan menangkal keluar atau masuknya penyakit dan/atau faktor risiko kesehatan masyarakat yang berpotensi menimbulkan kedaruratan kesehatan masyarakat". Adapun yang dimaksud dengan kedaruratan kesehatan masyarakat yaitu kejadian kesehatan masyarakat yang bersifat luar biasa dengan ditandai penyebaran penyakit menular dan/atau kejadian yang disebabkan oleh radiasi nuklir, pencemaran biologi, kontaminasi kimia, bioterorisme, dan pangan yang menimbulkan bahaya kesehatan dan berpotensi menyebar lintas wilayah atau lintas negara, (Vide: Pasal 1 angka (2) UU Kekarantinaan Kesehatan).

Peraturan tersebut mensyaratkan agar setiap warga negara Indonesia ikut berpartisipasi dalam penyelenggaraan kekarantinaan kesehatan. Sebagaimana diatur dalam Pasal 9 ayat (1) UU Kekarantinaan Kesehatan yang menyebutkan bahwasanya setiap orang wajib mematuhi penyelenggaraan kekarantinaan kesehatan. Hal ini akan menghasilkan sebuah asumsi bahwasanya setiap orang wajib mencegah "masuk atau keluarnya" suatu penyakit yang berpotensi menciptakan "kedaruratan kesehatan masyarakat".

Peran masyarakat Indonesia dalam mencegah penyebaran pandemi Covid-19 seperti yang terjadi saat ini merupakan sebuah upaya dari pembuat undang-undang mengatakan bahwa masyarakat Indonesia dapat dipidana jika tidak melaksanakan penyelenggaraan kekarantinaan kesehatan, sebagaimana yang diatur dalam Pasal 93 UU Kekarantinaan Kesehatan $a$ quo. Pertanyaan kemudian adalah perlu dan idealkah masyarakat dijadikan sebagai pencegah penularan suatu penyakit? Dan sudah tepatkah pengaturan terkait ketentuan pidana terhadap pelanggar penyelenggaraan kekarantinaan kesehatan?

Kebijakan hukum pidana (penal policy) terhadap perbuatan yang tidak mematuhi penyelenggaraan kekarantinaan kesehatan pada prinsipnya terlalu berlebihan. Upaya harus dilakukan oleh penegak hukum bersama pemangku kekuasaan adalah tindakan preventif, hal ini bersesuaian dengan prinsip ultimum remidium (pidana sebagai jalan terakhir). Pertimbangannya adalah apabila negara dalam keadaan darurat (kesehatan), terkadang penegakan hukum pidana bisa dikecualikan. Namun tetap mendahulukan tindakan pencegahan penyebaran penyakit menular terkhusus memanfaatkan tugas pokok dan fungsi dari tenaga kesehatan dan penegak hukum (penindakan bersifat ultimum remidium).

Hal di atas sejalan dengan pendapat dari Prof. M. Syukri Akub (Guru Besar Fakultas Hukum Universitas Hasanuddin) dalam sebuah Seminar Ujian Proposal Tesis Mahasiswa Pascasarjana Universitas Hasanuddin pada 9 Oktober 2020, mengatakan bahwa ketika terjadi 
pandemi Covid-19, penegakan sanksi pidana bisa dijadikan jalan terakhir, yang perlu didahulukan adalah pencegahan dan penanganan melalui penegakan tugas pokok dan fungsi tenaga kesehatan, baik dengan sosialisasi kesehatan maupun vaksinasi. Aspek lain yang disarankan adalah menerapkan sanksi yang sifatnya non pidana, seperti sanksi denda atau sanksi administratif bagi pelanggar kekarantinaan kesehatan khususnya di sektor pendidikan. Terlebih lagi rumusan pasal dalam ketentuan pidana UU Kekarantinaan Kesehatan terlalu asbtrak atau luas.

Kementerian Hukum dan Hak Asasi Manusia Republik Indonesia (Kemenkumham RI) telah mempraktikkan upaya preventif dalam menekan penyebaran Covid-19, dengan menerbitkan Peraturan Menteri Hukum dan Hak Asasi Manusia Nomor 10 Tahun 2020 tentang Syarat Pemberian Asimilasi dan Hak Integrasi Bagi Narapidana dan Anak dalam Rangka Pencegahan dan Penanggulangan Penyebaran Covid-19. Kemudian diikuti dengan peraturan pelaksananya, yakni Keputusan Menteri Hukum dan Hak Asasi Manusia Nomor M.HH-19.PK.01.04.04 Tahun 2020. Pengeluaran dan Pembebasan Narapidana dan Anak Melalui Asimilasi dan Integrasi dalam Rangka Pencegahan dan Penanggulangan Penyebaran Covid-19. Kebijakan tersebut tentunya menjadi upaya yang baik diterapkan ketimbang menjadikan pidana sebagai sanksi utama dalam menangani penyebaran Covid-19.

Apabila dilihat dalam Pasal 2 UU Kekarantinaan Kesehatan memuat asas perlindungan dan asas kedaulatan negara. Asas perlindungan berarti kekarantinaan kesehatan harus mampu melindungi seluruh masyarakat dari penyakit dan faktor risiko kesehatan yang berpotensi menimbulkan kedaruratan kesehatan masyarakat. Sedangkan asas kedaulatan negara berarti dalam penyelenggaraan kekarantinaan kesehatan harus mengutamakan kepentingan nasional dan ikut meningkatkan upaya pengendalian kedaruratan kesehatan masyarakat yang meresahkan dunia. Merujuk pada kedua asas tersebut, baik asas perlindungan maupun asas kedaulatan negara, keduanya mendahulukan upaya pengendalian (tindakan preventif) untuk mencegah terjadinya kedaruratan kesehatan masyarakat. Oleh karena itu, tindakan pengenaan sanksi pidana terhadap masyarakat yang melanggar kekarantinaan kesehatan sudah semestinya tidak menjadi keputusan yang utama harus diambil oleh aparat penegak hukum.

\section{Pemidanaan Terhadap Kegiatan yang Merintangi Darurat Kesehatan Masyarakat Pada Saat Penyelenggaraan Kekarantinaan Kesehatan}

Pemerintah Republik Indonesia telah menerbitkan Peraturan Pemerintah mengenai penyelenggaraan PSBB sebagai tindakan menekan penyebaran Covid-19 di Indonesia. PP PSBB tersebut merupakan derivasi 
TELAAH KETENTUAN PIDANA KEKARANTINAAN KESEHATAN BERDASARKAN UNDANGUNDANG NOMOR 6 TAHUN 2018 BAGI KESEHATAN NOTARIS DAN MASYARAKAT ERA PANDEMI COVID-19 (M. Aris Munandar, Audyna Mayasari Muin, Hijrah Adhyanti Mirzana) dari Pasal 59 ayat (1) UU Kekarantinaan Kesehatan yang berbunyi "Pembatasan Sosial Berskala Besar merupakan bagian dari respon kedaruratan kesehatan". Sebelumnya Pemerintah telah menerbitkan Keputusan Presiden Nomor 11 Tahun 2020 tentang Penetapan Kedaruratan Kesehatan Masyarakat Coronavirus Disease 2019 (Covid-19) dan Keputusan Presiden Nomor 12 Tahun 2020 tentang Penetapan Bencana Non Alam Penyebaran Coronavirus Disease 2019 (Covid-19) sebagai Bencana Nasional. Keseluruhan kebijakan tersebut merupakan prosedur formal dalam menangani setiap keadaan darurat kesehatan masyarakat.

Status darurat kesehatan masyarakat Indonesia yang telah ditetapkan melalui Keppres tersebut melegitimasi aparat penegak hukum untuk segera melaksanakan ketentuan pidana UU Kekarantinaan Kesehatan. Oleh karena itu, sebagai negara hukum (rechtsstaat), Indonesia wajib membuat dan melaksanakan hukum. Setiap produk hukum pidana yang dihasilkan, sebagaimana yang telah dijabarkan sebelumnya adalah harus memuat ketentuan yang dapat dilaksanakan di lapangan. Karena suatu undangundang hanya akan menjadi undang-undang mati jika pelaksanaannya terhenti. Apalagi jika undang-undang tersebut membuka potensi penafsiran analogi atau ekstensif.

UU Kekarantinaan Kesehatan merupakan produk hukum yang mengedepankan pemidanaan (primum remedium). Sedangkan dalam asas UU Kekarantinaan Kesehatan lebih mendahulukan aspek pengendalian dan pencegahan. Serta kekarantinaan kesehatan itu sendiri mengandung arti yang secara verbatimnya mengedepankan aspek pencegahan. Hal ini tentunya menimbulkan sebuah agumentum a contrario antara definisi kekarantinaan kesehatan dengan ketentuan pidana yang ada.

Suatu undang-undang pidana seyogianya ditafsirkan secara sempit sehingga antara ketentuan yang satu dengan lainnya dalam satu undangundang tidak menimbulkan ketidakpastian. Sebagaimana dikemukakan oleh restriktif (membatasi). J. Remmelink ${ }^{37}$ dalam bukunya menjelaskan bahwa mengenai ketentuan tegas bagaimana menjelaskan atau menafsirkan ketentuan pidana tidak akan ditemukan. Sekalipun ada kecenderungan umum yang menegaskan bahwa pada prinsipnya dalam hukum pidana kita harus melakukan interpretasi secara ketat (terbatas). Dalam Kitab UndangUndang Hukum Pidana Perancis (berlaku 1 Maret 1994) yang menetapkan: La loi poenale est d'interpretation stricte (hukum /KUHP harus ditafsirkan secara sempit, tidak secara luas).

Terlepas dari disharmonisasi antara asas dengan ketentuan pidana UU Kekarantinaan Kesehatan, persoalan selanjutnya adalah jenis

${ }^{37}$ J. Remmelink, Op.Cit., hlm. 53. 
pemidanaan yang dianut dalam UU Kekarantinaan Kesehatan itu sendiri. Dalam ketentuan pidana UU Kekarantinaan Kesehatan bahwa sanksi yang diberikan kepada pelanggar kekarantinaan kesehatan adalah "sanksi pidana penjara". Dalam KUHP Indonesia, sanksi pidana penjara merupakan hukuman yang lebih berat daripada pidana kurungan. Perbedaannya terletak pada hak-hak terpidana serta penerapan batas waktu pelaksanaan pidana. Wirjono Prodjodikoro ${ }^{38}$ dalam Tina Asmarawati menguraikan perbedaan pidana penjara dengan pidana kurungan, yaitu orang yang dijatuhi pidana penjara dapat menjalani dalam LAPAS di mana saja. Sedangkan pidana kurungan tidak dapat dijalankan di luar daerah di mana ia bertempat tinggal atau berdiam waktu pidana itu dijatuhkan; Orang yang dipidana penjara pekerjaannya lebih berat dari pidana kurungan; dan orang yang dipidana kurungan mempunyai hak pistole yakni hak untuk memperbaiki keadaannya dalam rumah penjara atas biaya sendiri. Sedangkan terpidana penjara tidak mempunyai hak tersebut.

Merujuk pada penjelasan di atas, maka jelas dalam ketentuan pidana UU Kekarantinaan Kesehatan mengandung sistem pemidanaan yang bersifat mutlak (absolut). Padahal dalam keadaan darurat kesehatan masyarakat, seharusnya aspek pemidanaan harus dijadikan jalan terakhir atau tidak diutamakan. Meskipun dibutuhkan, sanksi yang layak diberikan kepada pelanggar penyelenggaraan kekarantinaan kesehatan tidaklah melulu pidana yang bersifat mutlak (sistem pemidanaan mutlak/pembalasan). Mengingat keadaan darurat kesehatan tidak sama dengan saat situasi normal.

Contoh konkret penerapan Pasal 93 UU kekarantinaan kesehatan yang terkesan dipaksakan penerapannya, dapat dilihat pada Putusan No. 43/Pid.S/2020/PN.Mks. Dalam putusan tersebut terdapat 13 (tiga belas) terpidana yang didakwa menggunakan Pasal 93 UU Kekarantinaan Kesehatan jo. Pasal 55 ayat (1) ke-1 KUHP. Seluruh terpidana, menurut keyakinan Hakim ditambah alat bukti telah memenuhi unsur dalam Pasal 93 UU Kekarantinaan Kesehatan: "Yang tidak mematuhi penyelenggaraan kekarantinaan kesehatan dan atau menghalang-halangi sehingga menyebabkan kedaruratan kesehatan masyarakat" dan Pasal 55 ayat (1) ke1 KUHP: "Mereka yang melakukan, menyuruh melakukan dan turut serta melakukan perbuatan". Kasus tersebut bermula saat para terpidana melakukan kekerasan atau ancaman kekerasan melawan atau memaksa seorang pejabat yang sedang menjalankan tugas yang sah, atau orang yang menurut kewajiban undang-undang atau atas permintaan pejabat memberi pertolongan kepadanya dengan cara para Terdakwa masuk ke ruang Instalasi Gawat Darurat lalu ke ruang isolasi Covid-19 dan mengambil

${ }^{38}$ Tina Asmarawati, Op.Cit., hlm. 133-134. 
TELAAH KETENTUAN PIDANA KEKARANTINAAN KESEHATAN BERDASARKAN UNDANGUNDANG NOMOR 6 TAHUN 2018 BAGI KESEHATAN NOTARIS DAN MASYARAKAT ERA PANDEMI COVID-19 (M. Aris Munandar, Audyna Mayasari Muin, Hijrah Adhyanti Mirzana) paksa jenazah Alm. Muhammad Yunus kemudian dibawa ke rumah duka Jl. Rajawali I Lr. 13, Makassar. Amar putusan dalam putusan tersebut berbunyi:

1. Menyatakan Para Terdakwa Ahmad Rahman alias Dg. Tojeng, Syafri Amirullah Rajab alias Dg. Saung, Haris bin Arifin alias Bojes, Irwan Dg. Jarre, Muhammad Tahir Dg. Tika, Andi Yusuf alias Ucu bin Sinapude, Ramli Dg. Ngerang bin Nuhung, Murniati Dg. Jinne, Hamansiah alias Dg. Jime, Putri alias Puput, Bayani Dg. Jaja, Irna binti Ledeng dan Joharia binti Nasir Hatu alias Joha, telah terbukti secara sah dan meyakinkan bersalah melakukan tindak pidana "kekarantinaan kesehatan";

2. Menjatuhkan pidana kepada para terdakwa masing-masing selama 4 (empat) bulan;

3. Menetapkan pidana penjara tersebut tidak perlu dijalani oleh Para Terdakwa kecuali dalam tempo 8 (delapan ) bulan Para Terdakwa melakukan tindak pidana dan dijatuhi putusan lain.

Pada putusan di atas terlihat bahwasanya digunakan acara pemeriksaan singkat. Berdasarkan Pasal 203 ayat (1) Undang-Undang Nomor 8 Tahun 1981 tentang Hukum Acara Pidana (KUHAP), berbunyi "Yang diperiksa menurut acara pemeriksaan singkat ialah perkara kejahatan atau pelanggaran yang tidak termasuk ketentuan Pasal 205 dan yang menurut penuntut umum pembuktian serta penerapan hukumnya mudah dan sifatnya sederhana". Pasal 205 ayat (1) KUHAP berbunyi "Yang diperiksa menurut acara pemeriksaan tindak pidana ringan ialah perkara yang diancam dengan pidana penjara atau kurungan paling lama tiga bulan dan atau denda sebanyak-banyaknya tujuh ribu lima ratus rupiah dan penghinaan ringan kecuali yang ditentukan dalam Paragraf 2 Bagian ini”.

Putusan No. 43/Pid.S/2020/PN/ Mks tentang tindak pidana kekarantinaan kesehatan tersebut dianggap sebagai tindak pidana yang tidak tergolong dalam tindak pidana ringan. Yang menjadi pertanyaan besar dalam putusan tersebut adalah bagaimana hakim menginterpretasikan istilah "menyebabkan" sebagaimana unsur Pasal 93 UU Kekarantinaan Kesehatan? Tidak konkret dalam putusan tersebut dijelaskan mengenai hal demikian. Suatu putusan bisa dikatakan layak bilamana menerapkan peraturan yang memang bisa diterapkan. Serta tidak adanya penjelasan lengkap dari Majelis Hakim terkait perbuatan aktif dan pasif yang dilakukan oleh para terpidana sehingga memenuhi unsur Pasal 93 UU Kekarantinaan Kesehatan. Sedangkan secara expressis verbis pasal tersebut mengandung delicta commisionis per ommisionem commisa. 
Hukum hadir tidak hanya dalam menanggulangi kejahatan dan pelanggaran, melainkan juga sebagai salah satu alat kontrol/pengendalian sosial (law as a tool of social engineering). Seperti yang dikatakan oleh Abdul Manan ${ }^{39}$ dalam bukunya, bahwa peran hukum sebagai pengendalian sosial merupakan aspek normatif yang berlaku dalam kehidupan masyarakat, dapat berbentuk larangan, tuntutan, pemidanaan, dan biasa juga berupa pemberian ganti rugi. Lebih lanjut dijelaskan, bahwa peranan hukum sebagai alat pengendalian sosial, tidaklah berdiri sendiri dalam masyarakat, tetapi peranan itu dilaksanakan bersama dengan pranata-pranata sosial lainnya yang sama-sama menjalankan fungsi pengendalian sosial. Di sini hukum bersifat pasif, artinya hukum harus menyesuaikan diri dengan kondisi kehidupan masyarakat yang ada.

Pemidanaan yang layak diberikan terhadap pelanggar penyelenggaraan kekarantinaan kesehatan adalah berupa pemidanaan yang bersifat restoratif, yakni pemulihan keadaan kepada pelaku dan lingkungannya. Serta pemidanaan yang sifatnya integratif, yakni berupa pencegahan secara komprehensif atas suatu fatalitas darurat kesehatan masyarakat. Hal ini dikarenakan, penerapan pidana haruslah juga rasional atas suatu kondisi masyarakat. UU Kekarantinaan Kesehatan dibentuk atas dasar penanggulangan bencana non alam. Sehingga tepat jika pemidanaan terhadap pelanggar penyelenggaraan kekarantinaan kesehatan diarahkan pada pencegahan dan pemulihan.

\section{KESIMPULAN}

Kebijakan hukum pidana (penal policy) kegiatan yang menghambat atau merintangi penerapan status darurat kesehatan masyarakat dan notaris pada saat diselenggarakan kekarantinaan kesehatan masyarakat dan notaris tidak relevan untuk dilaksanakan dan ditegakkan. Ketentuan pidana UU Kekarantinaan Kesehatan mengalami kekaburan (obscuur libel) sehingga berpotensi untuk dilakukan penafsiran secara analogi. Selain itu, korelasi asas legalitas dengan rumusan tindak pidana sangatlah penting. Hal ini dikarenakan keberadaan asas legalitas dijadikan sebagai landasan pembentukan hukum guna menghindari ketidakpastian hukum secara komprehensif.

Sistem pemidanaan yang ideal diterapkan dalam mencegah penyebaran penyakit menular adalah pemidanaan yang berorientasi pada pencegahan (integratif) dan memulihkan keadaaan sosial (restoratif) bukan pemidanaan mutlak (absolut). Pemidanaan tersebut diharapkan bisa

${ }^{39}$ H. Abdul Manan, Dinamika Politik Hukum di Indonesia, Jakarta: Kencana Prenadamedia Group, (2018), hlm. 24. 
TELAAH KETENTUAN PIDANA KEKARANTINAAN KESEHATAN BERDASARKAN UNDANGUNDANG NOMOR 6 TAHUN 2018 BAGI KESEHATAN NOTARIS DAN MASYARAKAT ERA PANDEMI COVID-19 (M. Aris Munandar, Audyna Mayasari Muin, Hijrah Adhyanti Mirzana) mewujudkan penegakan hukum pidana yang bersesuaian dengan situasi dan kondisi kedaruratan kesehatan masyarakat. Sehingga penegakan hukum tidak hanya berorientasi pada aspek penghukuman berdasarkan pembalasan, melainkan sebagai upaya pemulihan keadaan baik untuk pelaku, masyarakat dan alam sekitarnya yang terpengaruh oleh tindakan pelaku yang tidak mematuhi peraturan perundang-undangan pidana.

Saran rumusan aturan yang dapat dijadikan sebagai bahan pembentukan peraturan perundang-undangan yang mengatur mengenai ketentuan sanksi terhadap orang yang melanggar protokol kesehatan pada saat terjadi wabah penyakit menular, antara lain:

(1) Setiap orang dengan sengaja tidak menggunakan masker di luar rumah, berkumpul atau berkerumun di tempat yang berpotensi mengakibatkan terjadinya penularan atau menambah jumlah penderita penyakit menular, atau tidak melaksanakan protokol kesehatan yang telah diatur dalam undang-undang ini dan/atau protokol kesehatan yang diatur dengan Peraturan Menteri Kesehatan pada saat terjadi wabah penyakit menular dikenai sanksi tindakan;

(2) Sanksi tindakan sebagaimana dimaksud pada ayat (1), berupa:

a) Pembubaran secara paksa;

b) Kerja Sosial;

c) Pencabutan izin mengemudi sementara waktu atau seumur hidup;

d) Kewajiban mengikuti karantina atau isolasi di rumah sakit atau tempat yang disediakan oleh Pemerintah hingga hasil pemeriksaan terbit.

(3) Tindakan sebagaimana dimaksud pada ayat (2) huruf a dikenakan kepada orang yang berkumpul atau berkerumun di tempat yang berpotensi mengakibatkan terjadinya penularan wabah penyakit menular;

(4) Tindakan sebagaimana dimaksud pada ayat (2) huruf b berupa membersihkan lingkungan sekitar atau kegiatan lain yang diatur dengan Peraturan Pemerintah;

(5) Tindakan sebagaimana dimaksud pada ayat (2) huruf c dapat diberikan sementara waktu yaitu 5 (lima) bulan atau seumur hidup apabila perbuatan yang dilakukan mengakibatkan fatalitas.

\section{DAFTAR PUSTAKA}

\section{Buku}

Arief, Barda Nawawi. Bunga Rampai Kebijakan Hukum Pidana. Bandung: PT. Citra Aditya Bakti, 1996. 
Angrayni, Lysa dan Hj. Yusliati. Efektivitas Rehabilitasi Pecandu Narkotika

Serta Pengaruhnya Terhadap Tingkat Kejahatan di Indonesia.

Ponorogo: Uwais Inspirasi Indonesia, 2018.

Asmarawati, Tina. Pidana dan Pemidanaan dalam Sistem Hukum di

Indonesia (Hukum Penitensier). Yogyakarta: Deepublish, 2015.

Darmodiharjo, Darji dan Shidarta. Pokok-Pokok Filsafat Hukum (Apa dan

Bagaimana Filsafat Hukum di Indonesia). Jakarta: PT. Gramedia

Pustaka Utama, 2006.

Hartini, Lilis. Bahasa dan Produk Hukum. Bandung: Refika Aditama, 2014.

Farid, H. A. Zainal Abidin. Hukum Pidana 1. Jakarta: Sinar Grafika. 2014.

Huda, Chairul. Dari Tiada Pidana Tanpa Kesalahan Menuju Kepada Tiada

Pertanggungjawaban Pidana Tanpa Kesalahan: Tinjauan Kritis

Terhadap Teori Pemisahan Tindak Pidana dan

Pertanggungjawaban Pidana. Jakarta: Kencana Prenadamedia

Group, 2011.

Ilyas, Amir dan Muhammad Nursal. Kumpulan Asas-Asas Hukum. Jakarta:

PT RajaGrafindo Persada, 2016.

Manan, H. Abdul. Dinamika Politik Hukum di Indonesia. Jakarta: Kencana Prenadamedia Group, 2018.

Munandar, M. Aris. Menilik Konsepsi Hukum, Hak Asasi Manusia, dan Keadilan (Suatu Kajian Teoretis). Makassar: Jariah Publishing Intermedia, 2019.

Pujiyono dan Ade Adhari. Hukum Pidana di Bidang Sumber Daya Alam.

Yogyakarta: Deepublish, 2019.

Remmelink, J. Pengantar Hukum Pidana Material 1, (Terjemahan Tristam

P. Meliono), Yogyakarta: Maharsa, 2014.

Sofyan, Andi dan Nur Azisa. Buku Ajar Hukum Pidana. Makassar: Pustaka

Pena Pers, 2016.

Sastrawidjaja, Sofjan. Hukum Pidana 1. Bandung: CV. Armico, 1990.

Sofian, Ahmad, Ajaran Kausalitas Hukum Pidana. Jakarta: Kencana Prenadamedia Group, 2018.

\section{Jurnal}

Kenedi, John. "Kebijakan Kriminal (Criminal Policy) dalam Negara Hukum Indonesia: Upaya Mensejahterakan Masyarakat (Social Welfare)", Jurnal Pemerintahan dan Politik Islam: Al-Imarah 2, No. 1 (2017).

Lathif, Nazaruddin. "Teori Hukum Sebagai Sarana/Alat Untuk Memperbaharui Atau Merekayasa Masyarakat", Jurnal Pakuan Law $\begin{array}{lllll}\text { Review } & 3, & \text { No. } & 1 & \text { (2017). }\end{array}$ https://journal.unpak.ac.id/index.php/palar/article/download/402/328 
TELAAH KETENTUAN PIDANA KEKARANTINAAN KESEHATAN BERDASARKAN UNDANGUNDANG NOMOR 6 TAHUN 2018 BAGI KESEHATAN NOTARIS DAN MASYARAKAT ERA PANDEMI COVID-19 (M. Aris Munandar, Audyna Mayasari Muin, Hijrah Adhyanti Mirzana)

Riana, Rati dan Muhammad Junaidi. "Konstitusionalisasi Pembentukan Peraturan Perundang-Undangan Melalui Penggunaan Bahasa Indonesia Baku", Jurnal Legislasi Indonesia 15, No. 4 (2018). https://e-jurnal.peraturan.go.id/index.php/jli/article/view/261.

\section{Internet}

Covid19.go.id. "Peta Sebaran", Tersedia online https://covid19.go.id/petasebaran.

Kompas.com. "WHO Resmi Sebut Virus Corona Covid-19 Sebagai Pandemi Global", Tersedia online https://www.kompas.com/sains/read/2020/03/12/083129823/whoresmi-sebut-virus-corona-covid-19-sebagai-pandemiglobal?page $=$ all. 